\title{
Articles
}

Central European Review of Economics \& Finance

Vol. 22, No. 6 (2017), pp. 29-40. D0I: 10.24136/ceref.2017.025

Katarzyna Sieradzka ${ }^{1}$

\section{SOURCES OF FINANCING FOR INNOVATIVE BUSINESS ACTIVITIES IN POLAND}

Financing of innovative business activities at early stages of their development is an extremely important condition of their growth. Start-ups, facing limited access to the formal capital market, look for an alternative. This is the informal market of capital investors, venture capital funds, and increasingly popular crowdfunding. It is the objective of this paper to analyse and evaluate sources of financing for innovative start-ups.

JEL Classification Codes: L210, L260.

Keywords: start-ups, business angels, venture capital, crowdfunding.

\section{Introduction}

Financing of new-formed innovative undertakings involves securing funds for projects whose capital requirements are (in most cases) greater than assets held by an entrepreneur/owner. Obtaining financing consists in proving business plans are promising and their realisation is viable and run by competent management. Start-up enterprises, a major source of innovativeness in a national economy, are analysed. Most start-ups are micro and small enterprises that begin their operations on the basis of an innovative idea. As their access to the formal capital market is limited, start-ups look for alternatives, including informal investors, high risk, mainly venture capital funds, and increasingly common crowdfunding.

\footnotetext{
${ }^{1}$ Assistant Professor, Ph.D., University of Technology and Humanities in Radom, Faculty of Economic and Legal Sciences.
} 
It is the objective of this paper to assess and analyse sources of financing for innovative activities of start-up enterprises. To this end, the following research hypotheses have been adopted:

H1: Innovative enterprises at initial stages of their development need specific sources of financing;

H2: Equity is the key source of capital for start-ups;

H3: Informal investors are a major source of capital for new, innovative business initiatives.

For the purposes of achieving the objective and demonstrating the hypotheses, data and information are analysed. provided by Polish and international institutions and organisations of the formal and informal financial markets.

\section{Specific forms of financing for start-up enterprises}

Private equity (PE) and venture capital (VC) funds are instruments investing in private, unquoted enterprises, usually in the medium to long terms. Private equity encompasses a broader swathe of the financial market, including segments like: venture capital, buyout capital, mezzanine and property funds. Their different interpretations arise from specific features of each market. VC capital is invested in other than public entities at early stages of their development.

The venture capital market is divided into its formal and informal parts. The former is primarily represented by venture capital funds, the latter by business angels.

\section{High-risk funds - Venture Capital}

Venture capital funds are closed-end, with a group of investors outlaying their capital on development of enterprises in early phases of development, characterised by a high risk but capable of high returns. "Venture capital is equity external investors bring for a limited time to small and medium-sized enterprises that have products, production methods or services that pose a great risk of investment failure but, if the undertaking supported by investors succeeds, provide a substantial growth in value of invested capital, realised by way of selling shares' (Węcławski, 1997, s.17).

VC funds commonly invest in innovative projects based on state-of-the-art technologies. The possibility of financing risky projects that would not otherwise find classic sources of funding like bank credit is the advantage of this 
type of investments. Extensive knowledge and management qualifications (employed in the process of project development) are additional strengths of such funds. Venture capital investments boost credibility of a firm in the eyes of other funds and institutions (e.g. banks). Their principal drawbacks comprise lower valuation than in a public offering and impossibility of a specialist transfer of know-how (in the case of a sectoral investor).

Private investors, banks, large enterprises, pension funds, insurance companies, public institutions are primary providers of capital.

Venture capital funds invest in enterprises at various stages of development, therefore, several phases of investing are distinguished:

- Seed financing,

- Start-up financing,

- Later stage financing,

- Growth financing,

- Financing of buyout operations.

Financing for the initial stages of enterprise development (seed and startup) is the greatest challenge to investors in organisational, specialist and financial terms; added to all that, these stages are liable to above-average risks. In the seed phase, capital is spent to build prototype products, conduct market research or prepare a business plan. At the start-up stage, the risk capital is allocated to establishing a business or launching of a product. At the time of growth and expansion, the capital is used to finance considerable investment requirements or roll out a distribution network by means of cofinancing or capitalisation (limited share issue). Buyout financing consists in financing of share acquisition by existing management from owners or share acquisition by an external management team who will take over at the firm.

The figures published by the European Equity and Venture Capital Association (EVCA) suggest value of such investments in Poland amounted to approx. $€ 800 \mathrm{~m}$ in 2015 , more than triple that in the preceding year $(€ 251 \mathrm{~m})$. With regard to numbers of investments, venture capital funds accounted for $61 \%$ of all private equity (PE) transactions. In respect of value, investments into growth and buyout phases prevailed, constituting $98 \%$ of the overall value of the PE transactions.

Analysis of shares of the particular investment stages in venture capital financing in Poland shows investments in start-ups are the most important in terms of both numbers and values (Fig. 1). 


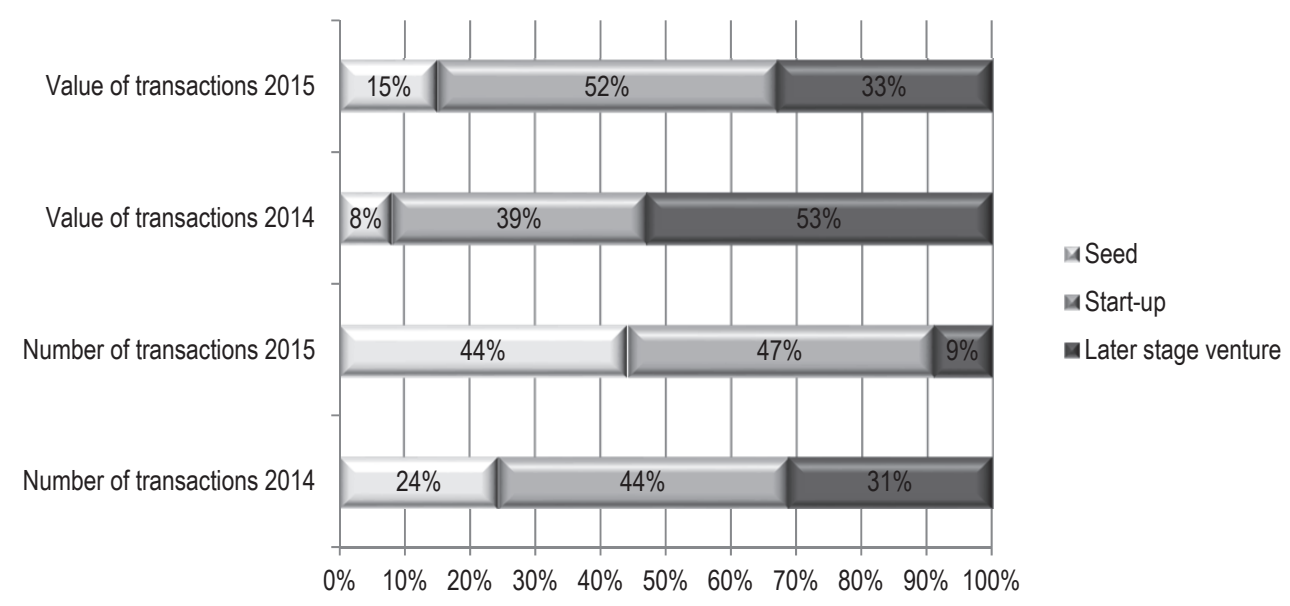

Figure 1. Shares of the particular investment stages in venture capital investments in Poland

Source: Rynek private equity w Polsce. Trendy i szanse rozwoju, Raport KPMG, Warszawa 2016, s. 18.

In 2015 , vC investments in start-ups accounted for $47 \%$ of transaction volumes, $13 \%$ more than a year before. They constituted $52 \%$ of the total value of transactions involving these funds. The growing significance of financing for seed investments is especially notable. Value of these transactions is low, yet clearly tends to rise. Prior to 2012, seed investments were rare, yet growing ranks and specialisation of venture capital funds have raised the numbers and values of the transactions. As a result, they accounted for a quarter of all VC transactions in 2014 and more than 40\% a year later.

Private equity in 2015 was invested in firms operating in sectors of computers and consumer electronics (23\%), business services (16\%), IT technologies, media and communications (11\%), medicine and pharmaceuticals (10\%). The large share of consumer electronics in PE investments is a result of the high incidence of venture capital investments in this sector.

\section{Business Angels (BA)}

Informal private investors, referred to as business angels, increasingly often fill the market gap arising from capital deficits. These denote individuals who allocate their own financial resources to new, most frequently innovative business undertakings. Aside from financial support, they offer specialist assistance, know-how, qualifications, market knowledge and business con- 
tacts. BAs are people who have been successful in the market, therefore, they know the market and understand risk and are thus able to effectively help entrepreneurs to create and manage a firm and construct its development strategy. In return, business angels expect to share in profits. 'Business angels are entrepreneurs and business people of substantial professional experience, whose work has generated substantial private assets, investing their savings at arm's length for a few years in shares of small and mediumsized enterprises which are not quoted in the public market, normally at early stages of development and displaying high potential of value growth' (Tamowicz, 2007, p. 7). Thus, the role of business angels is not limited to that of key capital providers. They fulfil essential functions in supporting innovativeness and building of competitive advantage.

National and international sources characterise business angels as males aged over 40, most often with education in economics, successful in the market and willing to invest their funds in new, innovative, high-risk business undertakings, expecting high returns on their invested capitals.

In the process of making decisions to accept or reject a project, business angels normally analyse the following factors (Mirowska, 2002, p. 85):

- Financial condition of an enterprise,

- Innovativeness of a product or service,

- Industry, sector and standing of a given market in the economy,

- Competences, experience and commitment of management staff,

- Possibility of active involvement in the enterprise's operations,

- Risk of an undertaking, very high in the case of investments financed by business angels,

- Location of the enterprise - 'angels' prefer close and frequent contacts with management and insights into progress of an undertaking.

Increasingly often, however, 'those relating to entrepreneurs and enterprise teams are the key group of factors influencing the angels' decision. In this way, investors appreciate the value of human capital while cutting their agency costs. Criteria connected to the nature of an enterprise opportunity, such as features of a product, market or financial prospects, are somewhat less important. To use a metaphor applied in research into the interface of the capital market and entrepreneurship, business angels may be said to invest in jockeys rather than horses, therefore'(Morawczyński, 2014, p. 302).

Private investors are normally reluctant to show off the monies they are willing to invest. They treasure their anonymity as a rule. To facilitate contacts between investors, enterprises and entrepreneurs, the so-called business angel networks are built to coordinate information flows between investors and en- 
trepreneurs. Angels are provided with access to investment propositions and entrepreneurs with access to external financing. This is the entire coordinating role of the networks. Both the parties, i.e. investors and entrepreneurs, make their investment decision on their own and at their own risk. Angels prefer local investments (geographical vicinity), that is, close distance and possibilities of quick contact, as well as knowledge of a sector are major factors in selection of projects. As a business angel shows genuine interest in a young innovator and their project, they are supplied with documents to conduct the due diligence process of a company or a young investor (analysis of business plan, talks with their originator and directors, verification of references and histories of the entrepreneur and potential management, telephone interviews with current and potential clients of the enterprise, talks with strategic partners and lawyers, discussion of the undertaking with potential cooperating firms, expert consultations regarding potential of a given product). If, in effect of the due diligence procedure, a business angel is still willing to invest in the firm, or even the innovator, terms and conditions of an agreement are negotiated, including sums of capital to be committed and ownership structure. Business angel's exit from the investment matters as well. 'Disinvestments from 40\% of enterprises are carried out by generating financial losses. In $26 \%$ of the projects, a business angel sells their shares to a strategic (sectoral) investor, $16 \%$ of business angels sell their shares to other investors, including to external investors in $10 \%$ of the projects. As a consequence, disinvestment by floatation or management buyout is carried through in merely $8 \%$ of the cases (Dąbkowski, 2015, p. 25).

Business angel networks are currently estimated at 470 organisations in Europe and 340 in the U S. EBAN - European Business Angels Network - is the largest organisation of this type in Europe. POLBAN - Polish Business Angels Network, linked with Polish Private Equity and Venture Capital Association (SIK) - operates in Poland. EBAN is a platform for sharing experience among the European Union countries, with POLBAN a member of the network. Business angels are currently active in all European countries and number 300000 individuals. They invested a record $€ 6.1 \mathrm{bn}$, or $71 \%$ of total investments in innovative undertakings, in 2015. ${ }^{2}$

EBAN data show 411 informal investors were active in Poland in 2015, who invested $€ 12.35 \mathrm{~m}$ in 32 investments (Table 1). The Polish business angel market is developing, as demonstrated with rising numbers of investors and overall value of their investments, as well as the network's expansion.

${ }^{2}$ Figures sourced from: www.eban.com [accessed on 27.05.2017]. 
Table 1. Business angels' investments in Poland (after EBAN)

\begin{tabular}{|l|c|c|c|}
\hline \multicolumn{1}{|c|}{ Specification } & $\mathbf{2 0 1 4}$ & $\mathbf{2 0 1 5}$ & YoY \\
\hline No. BANs & 4 & 5 & $\uparrow 25 \%$ \\
\hline No.Bas & 160 & 411 & $\uparrow 156 \%$ \\
\hline No.Investments & 38 & 32 & $\downarrow 15 \%$ \\
\hline Total BA Investment 2015 (€ m) & 9.5 & 12.35 & $\uparrow 23 \%$ \\
\hline Average Investment per BA (€ K) & 41125 & 30049 & $\downarrow 27 \%$ \\
\hline Average Investment per BAN (€ m) & 1.6 & 2.4 & $\uparrow 56 \%$ \\
\hline Average Investment per Company & 173158 & - & - \\
\hline Jobs created & 233 & - & - \\
\hline
\end{tabular}

Source: The author's own compilation on the basis of EBAN data, www.eban.com [accessed: 27.05.2017].

Examples of business angel investments are Google, Amazon and Uber, firms that, in their creativity and innovativeness, have come up with previously unheard-of services. Until they emerged, markets of Internet advertising (Google), online sales (Amazon) or genuine competition for taxis (Uber) had been virtually non-existent. Business angels are also visible in the domestic market, for instance: ${ }^{3}$

- Polidea - specialising in development of applications and transfer of content to mobile equipment. The business was established in mid-2009 following investments by two business angels: Tomasz Grzybowski and Krzysztof Gawrysiak, who invested less than PLN 100,000. In return, they acquired $40 \%$ shares. Owing to their contacts and commitment of the management team, Polidea signed a big contract with a foreign client as early as in the first weeks of its operation. After eighteen months, they employed 30 people and worked for global and domestic market leaders like Allegro or Onet. They have built a unique publishing platform for mobile devices - Pixblish. It is used by Polityka weekly, introducing its contents to tablets.

- W biegu cafe - a chain of cafes opened in major cities (Warsaw, Łódź, Kraków, Wrocław, Sopot, Gdańsk), a total of 18 at the moment, most located in city centres or big malls. Its CEO, Maciej Adamaszek, declares he wants to open 7-10 new outlets a year. He started the business with his savings in 2005. That was only enough for the first two cafes - one in Kraków and Warsaw each. He sought financing for further development

\footnotetext{
${ }^{3}$ Sourced from: www.pi.gov.pl [accessed on 27.05.2017].
} 
with banks and VC funds. He managed to find it, via Lewiatan Business Angels, with Piotr Pośnik, who decided to invest several million zlotys (acquiring $50 \%$ shares in return).

\section{Community financing (crowdfunding)}

Venture capital funds and business angels have been increasingly active at financing new, innovative investment undertakings since early 1990s. Market requirements exceed these finance capacities, however. Development of web sites (the so-called Web 2.0) and the possibility of micro-payments, both domestic and international transfers, have paved the way for a new source of financing for business ideas. This is community financing, referred to as crowdfunding. It may compete with alternative capital funds in future. Contrary to other forms of business financing, it can also be used for other than business purposes (e.g. charity, sports).

Crowdfunding is a method of collecting capital form the Internet community in order to finance a new project in return for a pre-arranged consideration (e.g. share in profits). Any business, scientific, cultural or social undertaking may be funded. In respect of business, it can be establishment of a new firm, launching of a new product/ service, for instance. High numbers of investors (donors) paying minor sums is characteristic for this way of financing. The collection is carried out on specific, specialised Web platforms. 'Crowdfunding is a type of collecting and allocation of capital to develop a specific undertaking in return for agreed-upon performances which involves a broad range of capital providers, uses IT technologies and has lower entry barriers and better terms of transactions than those generally available in the market" (Król,2013).

Future sharing of profits or co-ownership of a project are some forms of consideration for a community financing a given project. This is the so-called equity crowdfunding, used to finance new business projects, or start-ups. Material prizes, bonuses or other items may serve as consideration. With regard to forms of consideration for financial support, three types of crowdfunding are distinguished (Boniewicz, 2015, p. 58):

1) Equity - in exchange for financial support, investors receive shares in a project or other property rights like bonds. In effect, this form is dedicated to enterprises pursuing business projects; 
2) Loan-based - an auction system on the micro scale. A borrower, usually a private individual, may obtain a loan for a goal of their choice by means of a specialised platform. Each loan is funded by a group of people;

3) Donation-based - reward-based and the so-called sponsorship. The former is pure charity and no considerations other than possible expressions of gratitude are expected. Projects as part of this model are realised for the public good, that is, not for profit, and are commonly initiatives of foundations or organisations, though private individuals may be their ultimate beneficiaries as well. As part of the sponsorship model, a project originator clearly determines the way a donor will be rewarded depending on the sums in question. A reward is obligatory in this case. The sponsorship model is most often taken advantage of by private persons, with projects either commercial or non-profit.

Development of crowdfunding is in fact connected with emergence of the Web platform Kickstarter.com in 2009, though the idea itself goes back a far longer time. Kickstarter is the best recognisable crowdfunding platform globally. It reaches to entities seeking capital in a variety of fields, mostly in creative industries. Until 2015, 13 million people had supported its projects with a total of $\$ 3.1 \mathrm{bn}$, successfully financing 125352 projects (35\% o all submitted $)^{4}$.

The US crowdfunding market totalled $\$ 4 \mathrm{bn}$ and the UK market GBP $1.74 \mathrm{bn}$ in 2014. The global market in 2015 is estimated at 7-8 billion dollars. The World Bank forecasts its value will reach \$93bn in 2025 (Mazurek, 2014). The Polish community financing market is small, with several donation (e.g. Polakpotrafi.pl, Siepomaga.pl), loan-based (e.g. Finansowo.pl, Kokos.pl) and two equity funds (Beesfund.pl and Crowdangels.pl). Polakpotrafi.pl is the first and one of the largest crowdfunding portals in Poland. It was established following the model of the American Kickstarter at the Poznan University of Technology in 2011. It is based on the donation model and features prizes. Till 2017, 186255 users paid more than PLN 17,732m. 1400 out of 3001 projects submitted (that is, $47 \%$ ) have been successful. The largest project attracted PLN 385,600 from 3688 users $^{5}$.

Crowdfunding is the latest form of obtaining finance for often unconventional, innovative projects. Creators submitting their projects to a platform gain not only monies but also a variety of non-financial benefits, including:

\footnotetext{
${ }^{4}$ Sourced from: www.kickstarter.com [ accessed 20.05.2017]

${ }^{5}$ Sourced from: www.polakpotrafi.pl [accessed 20.05.2017]
} 
verification of the project, marketing tools and extensive access to the Internet community. Beside the undoubted advantages, a number of shortcomings of crowdfunding are indicated, such as lack of legal regulation in Poland, absence of consulting and monitoring of undertakings, and of security guarantees for investors, as they are not stipulated by law.

\section{Financing of start-ups in Poland}

Searching for new sources of financing for new enterprises is a major challenge to their owners. It decides survival and development of these firms in the market.

Studies of Polish start-ups indicate half of them rely exclusively on their own resources. As far as external sources are concerned, European Union funding (24\% of enterprises examined), venture capital funds (22\%) and business angels $(17 \%)$ are selected most frequently. Bank crediting was utilised by a mere $6 \%$ of the firms. Crowdfunding finances investments in $2 \%$ of Polish start-ups (Skala, Kruczkowska, 2016, p. 32)

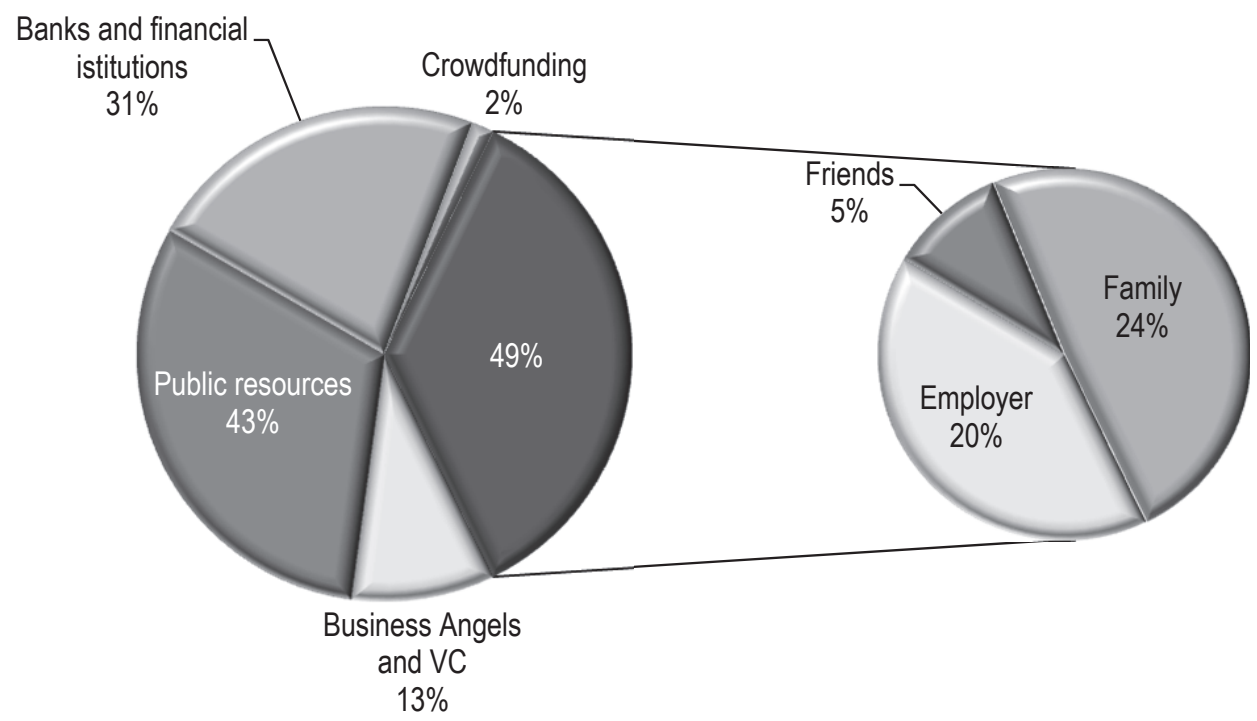

Figure 2. External sources of financing for new businesses in Poland in 2015 (multiple choice)

Source: The author's own compilation on the basis of: A. Tarnawa, D. Węcławska, P. ZaduraLichota, P. Zbierowski, Raport z badania - Global Entrepreneurship Monitor. Polska 2015, PARP, Warszawa 2016, p. 65. 
PARP's survey as part of GEM shows similar tendencies. Public monies were the chief source of financing at early stages of development (43\%), while $31 \%$ of the entities reviewed resorted to support from banks and financial institutions. Nearly a half took advantage of capital from informal investors, namely, family, friends or employers. $13 \%$ of the firms asked utilised venture capital and business angel funding. Start-ups gained a minimum of financing from crowdfunding, mainly because it is novel in the domestic market (Fig. 2).

GEM (Tarnawa, Węcławska, 2016) reports a starting enterprise had an average of PLN 100,000 in 2015. A half spent no more than PLN 42,000, though. PLN 58,000 were their own funds. Half of the enterprises spent less than PLN 30,000 to begin their operations.

\section{Conclusion}

Start-ups are micro or small firms that offer innovative products or services, have been in the market for a short time and run above-average risks. An efficient environment, the so-called ecosystem, is required for such undertakings to develop. Financing is one of its parts.

Financing of start-ups in the Polish ecosystem is relatively under-developed, due to low savings in the economy and poor network of institutional support, including business angels and venture capital funds, as well as tax incentives to invest in start-ups, inter alia. Analysis of literature and statistics suggests the following conclusions:

1. Own funds are the key source of financing early stages of business (50\%);

2. Capital of informal investors (family, friends, employers) and public resources (chiefly European Union funding) are the most commonly used external sources of financing: $49 \%$ and $43 \%$, respectively;

3. The Polish business angel market is developing, as proven with rising numbers of investors, the expanding network and growing total value of the investments, related to wealth of society and availability of financial surpluses;

4. Both own capital and funding by informal investors are assigned to investments liable to lower risks, proof of the essential role of higher-risk capitals;

5. In 2015, PE investments in Poland totalled $€ 803.5 \mathrm{~m}$, with a prevalence of venture capital investments (above 60\%); 
6. In 2015 , VC investments in start-ups accounted for $47 \%$ of the transaction volumes, $13 \%$ more than a year before. They constituted $52 \%$ of all transactions by these funds in Poland;

7. Crowdfunding is the latest way of securing finance for often unconventional, innovative projects. Crowdfunding accounted for investments in approx. $2 \%$ of Polish start-ups in 2015.

\section{References}

Brożek K., Kogut J., (2016), Econometric analysis of selected factors of innovative companies activity in the polish economy, Central European Review of Economics \& Finance Vol. 16, No. 6.

Dąbkowski A. (2015), Rynek inwestorów wysokiego ryzyka - Aniołowie Biznesu, KNUV Nr 4(46).

Mazurek J. (2014), Finansowanie społecznościowe czyli crowdfunding, Kurier Finansowy $\mathrm{Nr}$ 4(38),

Mirowska M. (2002), Venture Capital ze szczególnym uwzględnieniem business angels, „Folia Oeconomica” Nr 160, Wydawnictwo Uniwersytetu Łódzkiego, Łódź.

Morawczyński R.(2014), Kryteria inwestycyjne aniołów biznesu, Zeszyty Naukowe Uniwersytetu Szczecińskiego nr 803, Finanse, Rynki Finansowe, Ubezpieczenia $\mathrm{nr}$ 66, Szczecin.

KPMG (2016), Rynek private equity w Polsce. Trendy i szanse rozwoju, Raport, Warszawa.

Skala A., Kruczkowska E. (2016), Polskie start-upy. Raport 2016., Fundacja STARTUP POLAND.

Tamowicz P. (2007), Business angels. Pomocna dłoń kapitału, PARP, Warszawa.

Tarnawa A., Węcławska D., Zadura-Lichota P., Zbierowski P. (2016), Raport z badania - Global Entrepreneurship Monitor. Polska 2015, PARP, Warszawa.

Węcławski J. (1997), Venture capital. Nowy instrument finansowania przedsiębiorstw, Wyd. PWN, Warszawa.

www.eban.com

www.kickstarter.com

www.pi.gov.pl

www.polakpotrafi.pl 